\title{
The depression and related factors among cancer patients and their family caregivers in Turkish Population
}

\section{Türk Toplumunda kanserli hastalar ve yakınları arasındaki depresyon ve depresyonla iliş̧ili faktörler}

\author{
Başak Bala Öven Ustaalioğlu' ${ }^{1}$, Ezgi Acar ${ }^{1}$ \\ ${ }^{1}$ Haydarpaşa Numune Eğitim Ve Araştırma Hastanesi, Tıbbi Onkoloji Bölümü \\ ${ }^{2}$ Haydarpaşa Numune Eğitim Ve Araştırma Hastanesi, Psikiyatri Bölümü
}

\section{ÖZET}

GİRIŞ̧ ve AMAÇ: Kanserli hastalar arasında depresyon oranı \%29 olarak bildirilmiştir. Depresyon varlığı, hem hastayı, hem de hastaya bakmakla yükümlü aile üyelerini olumsuz yönde etkiler. Bu çalışmada, kemoterapi alan hastalar ve onlara bakmakla yükümlü yakınlarında depresyon varlığını, sosyo-demografik faktörler ve günlük aktivitelerin depresyonla ilişkisini değerlendirdik.

YÖNTEM ve GEREÇLER: Toplam 302 kanser hastası ve 302 yakınını inceledik. Depresyonu Beck Depresyon Envanteri (BDE) ile değerlendirdik. Depresyon için sınır değeri 17 olarak kabul ettik ve depresyonla ilişkili sosyodemografik özellikleri analiz ettik.

BULGULAR: Depresyon skorları hasta grupta yakınlarına göre daha yüksekti (12,5 ile 8). Hastalığı yeterince bilmeme, günlük sosyal aktivitelerde kısıtlılık, hem hasta hem yakınlarında depresyon varlığı ile ilişkiliydi. Korrelasyon analizi ile hasta yakınlarında, eğitim seviyesi, iş durumu, aylık gelir depresyonla ters orantılı iken, hastanın hastalığını bilme, depresyonla ilişkiliydi. Hastalar için ise, semptom varlığı, aile ziyaretleri, depresyonu predikte eden faktörlerdi. Bununla beraber, hasta yakınları için aile ziyaretleri ve aylık gelir depresyonu predikte eden bağımsız faktörler olarak bulundu.

TARTIŞMA ve SONUÇ: Hem hasta, hem de yakınlarında kültürel farklılıklar bazında depresyonu predikte eden faktörleri tesbit etmek, tedaviye yardımcı olacağı gibi hayat kalitelerinin de artmasına yardımcı olacaktır.

Anahtar Kelimeler: depresyon, kanser hastası, bakım veren aile üyesi, Beck depresyon envanteri, depresyon skoru

\begin{abstract}
INTRODUCTION: Depression has been reported as $29 \%$ in frequency among cancer patients. The presence of depression negatively effect both the patients and their family member who provide the care the patients. In the present study we evaluated the presence of depression in cancer patients receiving chemotherapy and their caregivers and the relatioship between socio-demographical factors and daily social activities with depression. METHODS: Totally,302 cancer patients and 302 family caregiver of them were evaluated. Depression was analyzed with Beck Depression Invantery(BDI). The cut-off value for depression was 17 and the sociodemograpfical factors related with depression were analyzed.

RESULTS: Depression scores was higher in patients then their caregivers(12.5vs8). Insufficent information about disease and rare social activities were related with depression for both cancer patients and their caregivers. By correlation analysis, educational level, occupational status and income were inversely related with depression but the knowing the the diagnosis of the patients by caregiver was positively related with depression. The presence of symptom and family visit were independent predicting factor for depression of patients. On the other hand family visit and income were important independent factors for caregiver depression.
\end{abstract}

DISCUSSION AND CONCLUSION: Findings of the predicting factor of depression for both patients and their caregiver according to culturel diversity may help treatment management and improve the quality of the life. Keywords: depression, cancer patients, family caregiver, Beck depression score, depression score. 


\section{Introduction}

Depression and anxiety are common psychiatric problemsin cancer patients (1). Patients with cancer experience a high disease load together with increased severity of disease as well as functional decline due to progression of their disease (2). In a meta-analysis included 70 studies, depression rate was reported as $16.3 \%$ with the $6.3 \%$ of them was major depression (3). For palliative care patients this rate increases up to $24.6-30 \%$ (4). Major depression rate was reported in the range of 5\% to $30 \%$ among cancer patients. The diversity for several studies related with different diagnostic criteria and interview types have been used. By clinical interview, questionnaires and self-report questionnaires with variable cut-off value depression can be diagnosed. Beck Depression Inventory (BDI) is specific for depression, it is a 21-item, self-report rating inventory that measures characteristic attitudes and symptoms of depression (5)

Patients with cancer and comorbid depression have worse anxiety, worse symptom like pain, fatique, poor adherence to treatment, impaired physical, social and family functioning than other cancer patient without combined depression $(1,6)$. Personal history of depression, being alone, low-socioeconomic status, lack of social support, type of cancer, advanced stage, uncontrolled physical symptoms, the presence of treatment toxicity and comorbiditieshave been reported as predictor factors for depression (4). To diagnose and management of depression which is linked with poor quality of life and shortened survival is important (7).

The diagnosis of cancer is recognized as chronic stressor not only for patients and also for their caregivers and effects negatively their psychological, social and economic status (8). Informal caregiver as family members provide care to cancer patients. Caregivers had been reported that higher depression score compared the age matched general population (8). Studies have shown that the rate of distress and psychiatric disorders among family caregiver were similar to those of the patients (9). Depression moods of carers of cancer patients was reported up to $70 \%$ (10). While younger age caregivers had higher depression score, relationship between gender, educational status, marital status and depression was contradictory (11). A few studies have addressed depression and the relationship between sociodemographical features of cancer patients and their family caregivers. To evaluate the factors predictors for depression of both cancer patients and their caregiver is important to allow more effective palliation and to improve survival of the patients.

Turkish family units are important in traditionally. People might feel responsible for looking after their family. The extended family included grandfather, grandson and their wives and the nuclear families included husband, wives and children are common in Turkey (12). One of the family member who lives with cancer patients takes all responsibility in diagnosis, treatment, follow-up and care of the patients. While generally family caregivers want to know diagnosis and decide treatment of the patients, they don't want patients to know all diagnosis and treatment detail sopsychological and social load of caregivers increase. Inhere we evaluated whether any the difference between depression scores of the patients and their caregivers. Furthermore we analyzed also any socio-demographic features or to know diagnosis abilty of affect the depression scores. Regular physical activity is not habit for our population. On the other hand traditionally family, friend or neighbor visits are frequent. We evaluated also frequency of the daily social activities of both patients and their caregivers and their relationship between depression scores.

\section{Material and Methods}

This is prospective cohort study of the case and performed between April 2016 September 2016. Totally 302 cancer patients who had been treated in outpatient chemotherapy unit of Haydarpasa Numune Education and Research Hospital in Istanbul and 302 caregivers of these patients were included. To be eligible for his study, patients had to have cancer and who had been treated with chemotherapy in our unit. Patients lived together with family members who weretheir primary caregiverswere included. Patients and their caregivers completed BDI quesitionnarse at the same time if they had no concurrent malignancy. Subjects need to be understand or communicate for the content of the questionnaireand had no cognitive disorders and were older than 18 years of age and they could read and understand 
Turkish.The participation was voluntary but all subjects provided informed consent for participation the study. After the questionnaires were completed, they were evaluated by one oncologist and one psychologist. Before begining the study, the permission from local ethical comittewas obtained.

Demographic datas including the age, gender, place of birth, marital status, education level, income, emplyoment status, presence of chronic or psychiatric disease were recorded for both patients and their caregivers. The cancer type, stage of the disease and treatment modalities were obtained from the patients'files. The daily social activities of subjects included visit of family members, neighbourhoud or friends, watcing television, having a picnic, going to cinema, eating out, shopping, going to holiday, walking together or shopping were queried. The number of daily activities which were performed by both patients and their caregivers were classified as none, 1-3, 4-6, 7-8 and 9-10.

Subjects were completed the Beck Depression Inventory (BDI) which is a 21-item, self-report rating inventory that measures characteristic attitudes and symptoms of depression (5). It takes approximately 10 minutes to complete, fifth - sixth grade reading level to adequately understand the questions (13). Turkish version of BDI which was pointed as reliable and valid for outpatient clinic by Hisli was used for our subjects (14). All items are scaled as 0-3. After subjects completed the questionnaire, thescore for each of the twentyone questions by counting the number to the right of each question they marked were added. The range of the total test was 0-63. The depression was classified as normal if the total score was between 0-10, 11-16 was minimal, 17-20 was borderline, 21-30 was intermediate, 31-40 was severe and >40 was exterme depression. The depression score of 17 as a cutoff point was used to diagnose the depression. If the depression scores was between 0 and 16 , it was accepted as normal, depression was diagnosed when the total score was $\geq 17$. Internal consistency for the BDI ranges from .73 to .92 with a mean of .86 . (15). The BDI demonstrates high internal consistency, with alpha coefficients of .86 and .81 for psychiatric and non-psychiatric populations respectively (15).

Statistical Analysis: Statistical analyses were performed using SPSS 17.0 (SPSS Inc., Chicago, IL, USA) software. The relationship between the presence of depression and sociodemographical factors were analyzed by the chi-squared test and Fisher's exact test.Furthermore we analyzed any relationship between depression score and sociodemographical factors and daily-social activities of all subjects by Sperman correlation test. The comparison of the depression scores of patients and their caregiver was analyzed by Mann-Whitney U-test. Factors found to be significant by chi-square were also examined with logistic regression analysis to determine predictive factors for depression. The $95 \%$ confidence (CI) was used to quantify the relationship between survival time and each independent factor. All $\mathrm{p}$ values were two-sided in tests and $p$ values less than or equal to 0.05 were considered to be statistically significant.

\section{Results}

Totally 604 subjects, 302 of them cancer patients and 302 were their caregiver were included the study. The median age of the patients and caregivers were 54 and 42 years respectively. Over the $60 \%$ of the patients and $48.7 \%$ of caregivers were female. Although over $95 \%$ of all subjects were placed in Istanbul, birth place of only $21.9 \%$ of the patients and $41.7 \%$ of the caregiver was Istanbul. Aproximately one third of subjects were lived with spouse and children as nuclear family. Nearly $10 \%$ lived with extentded family and $1.7 \%$ of patients lived alone. Most of the subject graduated from primary or high school. $52 \%$ of the patients and $32 \%$ of the caregiver were unemployed. Nearly $95 \%$ of the patient knew their disease. Caregiver of patients were spouse (43.2\%), children (44.9\%), mother or father (3\%) or sister $(9 \%)$. Table 1 shows the sociodemographic features of both patients and their caregivers. 
Table 1: The socio-demographic characteristic of the patients and patient caregivers

\begin{tabular}{|c|c|c|c|c|c|c|c|c|}
\hline & $\begin{array}{l}\text { Patients } \\
\text { Number }\end{array}$ & $\%$ & Median & Range & $\begin{array}{l}\text { Patients } \\
\text { caregiver } \\
\text { Number } \\
\end{array}$ & $\%$ & Median & Range \\
\hline Age & & & 54 & $27-84$ & & & 42 & $16-76$ \\
\hline Beck depression score & & & 12.5 & $0-50$ & & & 8 & $0-50$ \\
\hline $\begin{array}{l}\text { Gender } \\
\text { female } \\
\text { male }\end{array}$ & $\begin{array}{l}188 \\
114\end{array}$ & $\begin{array}{l}62.3 \\
37.7\end{array}$ & & & $\begin{array}{l}147 \\
155\end{array}$ & $\begin{array}{l}48.7 \\
51.3\end{array}$ & & \\
\hline $\begin{array}{l}\text { Place of residence } \\
\text { İstanbul } \\
\text { out of İstanbul }\end{array}$ & $\begin{array}{l}291 \\
11\end{array}$ & $\begin{array}{l}96.4 \\
3.6\end{array}$ & & & $\begin{array}{l}296 \\
6\end{array}$ & $\begin{array}{l}98 \\
2\end{array}$ & & \\
\hline $\begin{array}{l}\text { Birth place } \\
\text { İstanbul } \\
\text { out of İstanbul } \\
\text { Household } \\
\text { composition } \\
\text { spouse-children } \\
\text { Mother-father } \\
\text { Only mother or father } \\
\text { Extended family } \\
\text { alone } \\
\text { spouse } \\
\text { children alone }\end{array}$ & $\begin{array}{l}231 \\
5 \\
7 \\
31 \\
5 \\
11 \\
12\end{array}$ & $\begin{array}{l}76.5 \\
1.7 \\
2.3 \\
10.3 \\
1.7 \\
3.6 \\
4\end{array}$ & & & $\begin{array}{l}194 \\
51 \\
9 \\
35 \\
2 \\
9 \\
2\end{array}$ & $\begin{array}{l}64.8 \\
16.9 \\
3 \\
11.6 \\
0.7 \\
3 \\
0\end{array}$ & & \\
\hline $\begin{array}{l}\text { Educational level } \\
\text { literate } \\
\text { primary school } \\
\text { high school } \\
\text { associate } \\
\text { university } \\
\text { graduate }\end{array}$ & $\begin{array}{l}58 \\
164 \\
44 \\
12 \\
23 \\
1\end{array}$ & $\begin{array}{l}19.2 \\
54.3 \\
14.6 \\
4 \\
7.6 \\
0.3\end{array}$ & & & $\begin{array}{l}13 \\
125 \\
79 \\
18 \\
54 \\
13\end{array}$ & $\begin{array}{l}4.3 \\
41.4 \\
26.2 \\
6 \\
17.9 \\
4.3\end{array}$ & & \\
\hline $\begin{array}{l}\text { Employement status } \\
\text { student } \\
\text { officer } \\
\text { self-emplyoment } \\
\text { worker } \\
\text { housewife } \\
\text { retired } \\
\text { unemployed }\end{array}$ & $\begin{array}{l}6 \\
30 \\
21 \\
146 \\
86 \\
13\end{array}$ & $\begin{array}{l}2 \\
9.9 \\
7 \\
48.3 \\
28.5 \\
4.3\end{array}$ & & & $\begin{array}{l}20 \\
28 \\
79 \\
46 \\
73 \\
49 \\
7\end{array}$ & $\begin{array}{l}6.6 \\
9.3 \\
26.2 \\
15.2 \\
24.2 \\
16.2 \\
2.3\end{array}$ & & \\
\hline $\begin{array}{l}\text { Income } \\
\text { none } \\
<1000 \\
1000-2000 \\
>2000\end{array}$ & $\begin{array}{l}97 \\
65 \\
113 \\
27\end{array}$ & $\begin{array}{l}32.1 \\
21.5 \\
37.4 \\
8.9\end{array}$ & & & $\begin{array}{l}78 \\
47 \\
119 \\
58\end{array}$ & $\begin{array}{l}25.8 \\
15.6 \\
39.4 \\
19.2\end{array}$ & & \\
\hline
\end{tabular}




\section{Marital status}

$\begin{array}{lll}\text { single } & 10 & 3.3 \\ \text { married } & 250 & 82.8 \\ \text { widow } & 42 & 13.9 \\ \text { Chronic disease } & & \\ \text { present } & 72 & 23.8 \\ \text { absent } & 230 & 76.2 \\ \text { Psychiatric disease } & & \\ \text { present } & 19 & 6.3 \\ \text { absent } & 238 & 93.7 \\ \text { Does patient know his } & & \\ \text { dissease? } & & \\ \text { yes } & 286 & 94.7 \\ \text { no } & 16 & 5.3 \\ \text { Stage } & & \\ \text { 1 } & 11 & 3.6 \\ \text { 11 } & 53 & 17.5 \\ \text { 111 } & 108 & 35.8 \\ \text { 1V } & 130 & 43\end{array}$

\section{Operation}

present

absent

\section{Radiation}

present

absent

Symptom

present

absent

Family history

present

absent

Family caregiver

spouse

mother or father

child

sister

Beck categorical

values

normal

$130 \quad 43$

minumum

$77 \quad 25.5$

borderline

$37 \quad 12.3$

intermediate

severe

extreme
$194 \quad 64.2$

$108 \quad 35.8$

$74 \quad 24.5$

$228 \quad 75.5$

$91 \quad 30.1$

$211 \quad 69.9$

$69 \quad 22.8$

$233 \quad 77.2$

60

19.9

$226 \quad 74.8$

$16 \quad 5.3$

$43 \quad 14.2$

$259 \quad 85.8$

124

$290 \quad 96$ 
The median depression scores were 12.5(0-50) for patients and 8 (0-50) for their caregivers respectively and this value was statistically significant $(\mathrm{p}<0.001)$. Depression was more frequent in patients with advanced stage disease $(p=0.02)$ and patients who didn't know their disease $(\mathrm{p}=0.02)$ and also performed infrequent daily social activities $(\mathrm{p}=0.005)$. For patients caregivers, low income $(\mathrm{p}=0.001)$, history of psychiatric disease $(\mathrm{p}=0.03)$, rare social activities $\quad(p=0.002) \quad$ and sufficient knowledgeabout the disease of patients $(p=0.03)$ were together with depression. Marital status, household composition, family history of malignancy for patients or caregiver position as family member were not found related with presence of depression. Table 2 shows the relation between depression and sociodemographical characteristics.

By using correlation analysis, stage of the cancer was positively correlated with depressionamong patients $(\mathrm{p}=0.005$, $\mathrm{r}=0.110)$.On the other hand educational level $(\mathrm{p}=0.005, \quad \mathrm{r}=-0.163), \quad$ occupational status $(\mathrm{p}=0.008, \mathrm{r}=-0.153)$ and income $(\mathrm{p}=0.001, \mathrm{r}=$ 0.185 ) were inversely correlated with depression among caregivers but the knowing the the diagnosis of the patients by caregiver was positively related with depression $(\mathrm{p}=0.03$, $\mathrm{r}=0.121$ ).Table 3 the results of the related factors with Beck depression scores.

The most common daily social activities of Turkish populations were visit of family, friends, neighbour, going to cinema, eating out, having a picnic, shopping, watching television, going to holiday, walking together (Table 4). The number of daily social activities of both patients and their caregiver were classified as none, 1-3, 4-6, 7-8 and 9-10 and table 5 shows this classification for both groups.

The presence of symptom $(\mathrm{p}=0.01)$ and family visit $(\mathrm{p}=0.005)$ were independent predicting factor for depression for patients. On the other hand family visit $(\mathrm{p}=0.01)$ and income $(p=0.05)$ were important for caregiver depressionby logistic regression analysis.

\section{Discussion:}

Cancer is life-threatening disease so psychiatric disorders like anxiety and depression have been common among cancer patients (16). The rate of the depression in cancer patients is four times higher than general population (17). The prevelance of depression was reported as 3\% to $\% 38$ in cancer patients and highest rate related with advanced stage, disability, unrelieved pain (17). One metaanalysis included 211 studies reported the depression rate in cancer patients was $8 \%$ to $24 \%$ (18). This variabilities is caused by depression was measured by different instruments in different cancer types or stages (19). BDI was assessed as screening method for depression and it was considered favourable, generalized and potantially useful across cancer types and disease stage (20). Several reviews reported that BDI has appropiate sensitivity and specificity $(19,20)$. BDI is easy for use and quick to complete so we used this short test to determine depression score of both 302 patients and 302 their caregiver in the chemotherapy unit when they came to take chemotherapy. The median depression scores of patients were higher in patients compared than their caregivers (12.5 and 8 respectively). While $68.8 \%$ of the patients had depression, $18.6 \%$ of the healthy caregivers had intermediate or severe depression. Although traditional extended family still common in east part of Turkey, one third of our patients live in nuclear family in Istanbul so caregivers were mostly spouse $(43.2 \%)$ or children (44.9\%).Several factor have been reported as risk factors for depression like younger age, low socioeconomical status, social isolation, past depression, advanced stage disease, toxic effect of chemotherapy regimen, presence of symptom, functional impairment (21). While in general population depression is more prevelant in women, depression rates are similar in both gender and age among cancer patients (17).Over the $60 \%$ of the our patients and $48.7 \%$ of caregiver were female and depression was not different between male or female group.

Walker et al. screened depression in 21151 cancer patients (6). Major depression was frequent in lung cancer, gynecological cancer, breast, colorectal and genitourinary cancer. Betweeen these groups younger age and low social deprivation score were associated with more depression (6). And also oropharyngeal cancer, pancreatic, breast and lung cancer were reported more associated with depression (17). Advanced stage disease, lower performance, status have been reported to be related with severity of depression $(16,22)$. Most of diagnosis in our patients were breast (44.7\%), gastrointestinal system(37.7\%), lung (5.3\%), gynecological system (4\%), 
genitourinary system $(2.4 \%)$, head and neck cancer $(1.6 \%)$ and others in order of frequency. Although there was a no difference between cancer type and depression, advanged stage were asociated with higher depression similar the literature. Breast cancer is common in our center and the prognosis of breast cancer is relatively better than other cancer types so depression was not different according to cancer types with infrequently seen head and neck or pancreatic cancer.

Different from us, Mitchell et al. reported that depression was not different between healthy control and cancer patients (3). They didn't investigate the effect of the treatment, symptoms, work status and also they analyzed depression 2 years after from the diagnosis. We evaluated patients while taking median 4 cycle of the chemotherapy after the diagnosis so the negative effect of treatment toxicity on depression was included. Salvo et al. analyzed 1439 cancer patients and they reported that $55 \%$ of at least mild depression. They found that low performance, female gender, cancer type such as lung cancer were significantly associated with severe depression and pain was not independent factor for depression (16). Pscychological stress was reported as lower in breast cancer patients who had a job (23). Employed women had wider social enviroment so more self confidence. Socioeconomic status which was measured by annual income of family was important in determining quality of life of cancer patiens (23). In our study, 52\% of the patients and $32 \%$ of the caregiver were unemployed, but neither emplyoment status nor the other social parameters like income, educational levels were related with depression score among patients. The presence of symptom and family visit were only two independent predicting factor for depression.

The diagnosis of cancer leads to serious psychiatric distress the affected person as well as their close family member (24). Primary caregivers with female gender, spousal relationship, older age, poorer health, caring advanced stage patientswerefound to be more tendency for depression (25). Because of the closest support, partners have vital role in the care of cancer patients (24). In most studies caregivers was female and they reported that higher level of stress compared the male caregivers (26). Inhere $77.4 \%$ of caregivers were spouse of the patients andnearly half of them were female but no difference in respect to depression from the male caregiver were detected.Badr et al. analysed 49 patients with head and neck cancer who underwent radiotherapy and their caregivers. They found that both patients and their caregivers had similar paterns of changes in distress overtime but caregivers were more distressed than patients over the course of radiotherapy (27). It may be related head and neck radiotherapy disrupt daily activities more common than other cancer therapy which is more common in our center.

Grunfeld et al reported that cancer patients and their caregives experienced similar level of depression (28). Heckel et al. analyzed 150 caregiver of cancer patients with one third of them had depression score of 16 or above. $83 \%$ of them was partner and $39 \%$ educated from secondary school and $36 \%$ from the university (10). Caregiver depression score was not related with patients' demographical features (10). Stadfford et al also didn't find any relationship between caregivers' depression and patient depression and any clinical characteristics (29). As a family caregiver being older age and being a partner had negatively affect the quality of the life (24). Family caregivers play a vital role during treatment and follow-up time of cancer patients particularly in Turkey. Yesilbakan et al. evaluated symptom checklist of 80 cancer patients and their caregivers (30). Over $80 \%$ of the population was unemployed and $41 \%$ of them completed secondary school. Spousal relationship was common as $49 \%$ as caregiver. Among two groups depressive mood was higher among caregivers than cancer patients (30). We found that educational level, occupational status and income were inversely correlated with depression among caregivers. On the other hand marital status, household composition, caregiver position as family member were not found related with presence of depression.

Physical activity in cancer patients especially in breast cancer, has been shown to improve quality of life and reduce depression (31). Regular physical activity is not habit for our population. On the other hand traditionally family, friend or neighbor visits going to cinema, eating out, having a picnic, shopping, watching television, going to holiday, walking together are frequent. We evaluated also frequency of the daily social activities of both 
patients and their caregivers and their relationship between depression scores. For both patients and their family caregiver increasing the daily social activitie numbers were together with lower depression score.

Another issue, in our society, generally family caregivers want to know diagnosis and decide treatment of the patients, they don't want patients to know all diagnosis and treatment detail so psychological and social load of caregivers increase. Although nearly $95 \%$ of the patient knew their diseasehere, other 16 patients who didn't their diagnosis had worse depression score. In respect to family caregivers oppositely if they know their diagnosis detail, they had more depression. In all chemotherapy unit psychologist and work together multidisiplinary should be exist to explain diagnosis and oncological treatment plan, to patients and family caregiver together before starting the treatment. In addition nurses working in oncology unit should educated pscychological quidence to interwiev patients caregiver also.

This is one of the few study to compare depression score of both patients and their caregivers. We think that this study is important to mention the relationship between sociodemographical features and daily-social activities of both patients and their caregivers reflecting the West part of the Turkey.

Acknowledgement: This manuscript was not supported with any financial or other relationships. This work has been previously o rsimultaneously submitted to an other scientific journal.

\section{References}

1. 1.Addington-Hall J. The legacy of cancer on depression and anxiety. Lancet Oncol. 2013 ;14:6756.

2. Maltoni M, Caraceni A, Brunelli C, et al. Prognostic factors in advanced cancer patients: evidence-based clinical recommendations-a study by the Steering Committee of the European Association for 2005, Palliative Care J. Clin. Oncol. 2005;23:6240-6248.

3. Mitchell A.J. Prevalence of depression, anxiety, and adjustment disorder in oncological, haematological, and palliative-care settings: a meta-analysis of 94 interview-based studies. Lancet Oncol. 2011;12:160174.

4. Dauchy S, Dolbeault S, Reich M. Depression in cancer patients.EJC Suppl. 2013;11:205-15.

5. Beck AT, Ward CH, Mendelson M, Mock J, Erbaugh J. An inventory for measuring depression. Archives of General Psychiatry 1961; 4:561-571.
6. Walker J, Hansen CH, Martin P, et al. Prevalence, associations, and adequacy of treatment of major depression in patients with cancer: a cross-sectional analysis of routinely collected clinical data.Lancet Psychiatry. $2014 ; 1: 343-50$.

7. Lie HC, Hjermstad MJ, Fayers P, Finset A, Kaasa S, Loge $\mathrm{JH}$, on behalf of the European Palliative Care Research Collaborative(EPCRC) Depression in advanced cancer - Assessment challenges and associations with disease load Journalof Affective Disorders , 2015;173:176-184.

8. Bevans M, Sternberg EM. Caregivingburden, stress, and healtheffects among family caregivers of adultcancerpatients.JAMA. $2012 ; 307: 398-403$.

9. Vickery L, Latchford G, Hewison J, Bellew M, Feber $\mathrm{T}$. The impact of head and neck cancer and facial disfigurement on the quality of life of patients and their partners. Head Neck 2003;25:289-96.

10. Heckel L, Fennell KM, Reynolds J, et al. Unmet needs and depression among carers of people newly diagnosed with cancer.Eur J Cancer. 2015 Sep;51:2049-57

11. Swore Fletcher BA, Dodd MJ, Schumacher KL, Miaskowski C. Symptom experience of family caregivers of patients with cancer.Oncol Nurs Forum. 2008;35:E23-44

12. Hacialioglu N, Ozer N, Yilmazkarabulutlu E, Erdem $\mathrm{N}$, ErciB. The quality of life of family caregivers of cancer patients in the East of Turkey. European Journal of Oncology Nursing. 2010;14: 211-217

13. Groth-Marnat G. The handbook of psychological assessment (2nd ed.). 1990; New York: John Wiley \& Sons.

14. Hisli N. Beck Depresyon Envanterinin Üniversite Ö̋rencileri <çin Geçerliøi ve Güvenirliạ. Psikoloji Dergisi 1989;7:3-13.

15. Beck AT, Steer RA, Garbin MG. Psychometric properties of the Beck Depression Inventory: Twenty-five years of evaluation. Clinical Psychology Review, 1988;8; 77-100.

16. Salvo N, Zeng L, Zhang L, et al. Frequency of reporting and predictive factors for anxiety and depression in patients with advanced Cancer. Clinical Oncology, 2012; 24: 139e148

17. Snyderman D, Wynn D. Depression in Cancer Patients Prim Care Clin Office Pract; 2009; 36 :703719.

18. Krebber AM, Buff art LM, Kleijn G, et al. Prevalence of depression in cancer patients: a meta-analysis of diagnostic interviews and self-report instruments. Psychooncology 2014; 23: 121-30.

19. Wakefield CE, Butow PN, Aaronson NA, Hack TF, Hulbert-Williams NJ, Jacobsen PB; International Psycho-Oncology Society Research Committee. Patient-reported depression measures in cancer: a meta-review. Lancet Psychiatry. 2015;2:635-47.

20. Nelson CJ, Cho C, Berk AR, Holland J, Roth AJ. Are gold standard depression measures appropriate for use in geriatric cancer patients? A systematic evaluation of self-report depression instruments used with geriatric, cancer, and geriatric cancer samples. $\mathbf{J}$ Clin Oncol 2010; 28: 348-56.

21. Endicott J. Measurement of depression in patients with cancer. Cancer 1984; 53:2243-9.

22. Akechi T, Okuyama T, Sugawara Y, Nakano T, Shima Y, Uchitomi Y. Major depression, adjustment 
disorders, and post-traumatic stress disorder in terminally ill cancer patients: associated and predictive factors. J Clin Oncol 2004;22:1957e1965.

23. Ogce F, Ozkan S, Baltalarli B. Psychosocial stressors, social support and socio-demographic variables as determinants of quality of life of Turkish breast cancer patients.Asian Pac J Cancer Prev. 2007 ;8:7782.

24. Sjolander $\mathrm{C}$, Rolander $\mathrm{B}$, Järhult $\mathrm{J}$, Mårtensson $\mathrm{J}$, Ahlstrom G. Health-related quality of life in family members of patients with an advanced cancer diagnosis: a one-year prospective study.Health Qual Life Outcomes. 2012;10:89.

25. 25.Cunningham AJ, Edmonds CV, Jenkins GP, Pollack H, Lockwood GA, Warr D. A randomized controlled trial of the effects of group psychological therapy on survival in women with metastatic breast cancer. Psychooncology 1998;7:508-17.

26. Kim Y, Baker F, Spillers BS. Cancer Caregivers' Quality of Life: Effects of Gender, Relationship, and Appraisal. Journal of Pain and Symptom Management 2007;34:294-304
27. Badr H, Gupta V, Sikora A, Posner M. Psychological distress in patients and caregivers over the course of radiotherapy for head and neck Cancer. Oral Oncology, 2014; 50: 1005-1011

28. Grunfeld E, Coyle D, Whelan T, et al. Family caregiver burden: results of longitudinal study of breast cancer patients and their principal caregivers. Canadian Medical Association Journal 2004;170: 1795-1801.

29. Stafford L, Judd F. Partners of long-term gynaecologic cancer survivors: psychiatric morbidity, psychosexual outcomes and supportive care needs. Gynecol Oncol 2010;118:268-73.

30. Yeşilbalkan OU, Okgün A. Patients' self reports and caregivers' perception of symptoms in Turkish cancer patients.Eur J Oncol Nurs. 2010;14:119-24.

31. McNeely ML, Campbell KL, Rowe BH, Klassen TP, Mackey JR, Courneya KS. Effects of exercise on breast cancer patients and survivors: a systematic review and meta-analysis.CMAJ. 2006 ;175:34-41. 